\title{
Effects of a small, volatile bacterial molecule on Pseudomonas aeruginosa bacteria using whole cell high-resolution magic angle spinning nuclear magnetic resonance spectroscopy and genomics
}

\author{
VALERIA RIGHI $^{1-4}$, CATERINA CONSTANTINOU ${ }^{1,3}$, MEENU KESARWANI $^{3}$, \\ LAURENCE G. RAHME ${ }^{3}$ and A. ARIA TZIKA ${ }^{1-3}$
}

\begin{abstract}
${ }^{1}$ NMR Surgical Laboratory, Center for Surgery, Innovation and Bioengineering, Department of Surgery, Massachusetts General and Shriners Burns Hospitals, Harvard Medical School; ${ }^{2}$ Athinoula A. Martinos Center for Biomedical Imaging, Department of Radiology, Massachusetts General Hospital and Harvard Medical School; ${ }^{3}$ Molecular Surgery Laboratory, Department of Surgery, Microbiology and Immunobiology, Harvard Medical School and Molecular Surgery Laboratory, Center for Surgery, Innovation and Bioengineering, Department of Surgery, Massachusetts General and Shriners Burns Hospitals, Boston, MA 02114, USA
\end{abstract}

Received July 16, 2015; Accepted November 19, 2015

DOI: $10.3892 / \mathrm{ijmm} .2018 .3760$

\begin{abstract}
In the present study, high-resolution magic-angle spinning (HRMAS) nuclear magnetic resonance (NMR) spectroscopy was applied to live Pseudomonas aeruginosa (PA) bacterial cells to determine the metabolome of this opportunistic Gram-negative human pathogen, and in particular, its response to the volatile aromatic low molecular weight signaling molecule, 2-aminoacetophenone (2-AA). Multi-dimensional HRMAS NMR is a promising method which may be used to determine the in vivo metabolome of live intact bacterial cells; 2-AA is produced by PA and triggers the emergence of phenotypes that promote chronic infection phenotypes in in vitro and in vivo (animal) models. In the present study, we applied one-dimensional and two-dimensional proton $\left({ }^{1} \mathrm{H}\right)$ HRMAS NMR to PA cells which were grown with or without 2-AA in order to examine the associations between metabolites and cellular processes in response to 2-AA. We also compared whole-genome transcriptome profiles of PA cells grown with or without 2-AA and found that
\end{abstract}

Correspondence to: Dr A. Aria Tzika, NMR Surgical Laboratory, Center for Surgery, Innovation and Bioengineering, Department of Surgery, Massachusetts General and Shriners Burns Hospitals, Harvard Medical School, Boston, MA 02114, USA

E-mail: atzika@hms.harvard.edu

Present address: ${ }^{4}$ Department of Life Quality Studies, University of Bologna, Rimini Campus, Corso d'Augusto 237, 47921 Rimini, Italy

Key words: bacteria, Pseudomonas aeruginosa, in vivo high-resolution magic angle spinning, total through-bond correlation spectroscopy, genomics, metabolomics
2-AA promoted profound metabolic changes in the PA cells. By comparing the whole-genome transcriptome profiles and metabolomic analysis, we demonstrated that 2-AA profoundly reprogramed the gene expression and metabolic profiles of the cells. Our in vivo ${ }^{1} \mathrm{H}$ HRMAS NMR spectroscopy may prove to be a helpful tool in the validation of gene functions, the study of pathogenic mechanisms, the classification of microbial strains into functional/clinical groups and the testing of anti-bacterial agents.

\section{Introduction}

Pseudomonas aeruginosa (PA) is an ubiquitous Gram-negative bacterium that inhabits a wide array of natural environments, and is important in a clinical context, as it is a multi-antibiotic-resistant human pathogen associated with hospital infections $(1,2)$ and is a major cause of morbidity and mortality in patients with cystic fibrosis (CF). PA colonizes the lower respiratory and gastrointestinal tracts, as well as the mucosa and skin of hospitalized patients treated with broad-spectrum antibiotics. The development of chronic PA respiratory infections is mediated through a complex adaptive process that effects essential physiological changes in both bacterial cells and the host, that allow PA to survive and persist in the host environment. PA cells secrete small molecules that act as specific chemical signals to positively regulate pathogenic pathways (3), which direct the production of virulence factors for pathogenic infection, host colonization and interspecies microbial interactions (4). Knowledge on the bacterial signals required to promote the pathogen adaptation and/or transition from acute to chronic infection remains rudimentary (5).

Bacterial cell walls are complex, consisting of integrated macromolecules including carbohydrates, lipids and proteins (6). The structure and synthesis of these cell walls is unique, with many of the components not found anywhere else in nature (7). Current understanding of bacterial cell wall struc- 
tures is based on data derived from the destructive analyses of its individual components (7), and as such, this in vitro data may not faithfully reflect the native structural and conformational information. An alternative approach to such analyses is the non-targeted profiling of the physiological state of bacterial cells, such as metabolomic profiling.

Metabolomics is the comprehensive determination of the low molecular weight metabolite complement within a biological sample. As metabolites are downstream from gene transcription and enzyme activities, metabolomics has the potential to provide a more accurate snapshot of the actual physiological state of a cell or cells, as opposed to transcriptome and proteome profiling (8).

To this end, metabolomics has been used to study the responses of bacteria to different physiological states and stressors (9-11), and nuclear magnetic resonance (NMR) spectroscopy has been employed to profile microbial species for differentiation and classification, including in vivo profiles of yeast strains, and of marine unicellular algae via magic-angle spinning (12).

Cell high-resolution magic-angle spinning (HRMAS) NMR spectroscopy can be used to distinguish detailed structures present on bacteria $(13,14)$. Moreover, multi-dimensional HRMAS NMR is a powerful tool for the in vivo analysis of live bacterial cells (15). HRMAS is a novel non-destructive methodology that substantially improves spectral line-widths to allow high-resolution spectra to be obtained from intact cells, cell tissue cultures $(16,17)$ and unprocessed tissues $(18,19)$. ${ }^{1} \mathrm{H}$ HRMAS NMR has also enabled the investigation of the associations between metabolites and cellular processes (21), and NMR spectroscopic analyses have reported the presence of bacteria and PA on extracted cells (22). To avoid chemical modifications by the extraction/purification of metabolites, and to maintain cell integrity, in the present study, we applied HRMAS NMR methodology to live PA to characterize and quantify the metabolic profile of these cells and their surface structures. We also specifically focus on specific metabolites that are likely involved in PA-mediated host inflammation.

\section{Materials and methods}

Cell samples. The PA strain used in the present study was RifR human clinical isolate UCBPP-PA14. The mutants of PA14 described in this study are isogenic to UCBPP-PA14. The bacteria were grown at $37^{\circ} \mathrm{C}$ in Luria-Bertani (LB) broth or on plates of LB agar containing appropriate antibiotics or the compounds, unless mentioned otherwise. The overnight PA14 cultures were grown in LB and diluted the following day in fresh medium in triplicate. A total of $10 \mathrm{ml}$ of culture adjusted to an $\mathrm{OD}_{600}$ of $2.0 \mathrm{~nm}$ was centrifuged, and the pellet was washed once with PBS.

NMR spectroscopy. Following bacterial growth in LB to an $\mathrm{OD}_{600}$ of 2.5 , bacterial samples (50 and $\left.40 \mu \mathrm{l}\right)$ were introduced into the 4-mm $\mathrm{Zr}$ rotor and $10 \mu \mathrm{L} \mathrm{D}_{2} \mathrm{O}$ (deuterium lock reference) containing $10 \mathrm{mM}$ trimethylsilyl propionic-2,2,3,3- $\mathrm{d}_{4}$ acid (TSP; $M_{w}=172, \delta=0$ ppm, external chemical shift reference) was added to the rotor with the sample plus $10 \mu \mathrm{TSP} / \mathrm{D}_{2} \mathrm{O}$ solution $(50 \mathrm{mM}) .{ }^{1} \mathrm{H}$ HRMAS NMR spectroscopy experiments were performed on a Bruker Bio-Spin Avance NMR spectrom- eter $(600.13 \mathrm{MHz})$ using a 4-mm triple resonance $\left({ }^{1} \mathrm{H},{ }^{13} \mathrm{C},{ }^{2} \mathrm{H}\right)$ HRMAS probe (Bruker Biospin Corp, Billerica, MA, USA). The temperature was controlled at $4^{\circ} \mathrm{C}$ by a BTO-2000 unit in combination with a MAS pneumatic unit (Bruker).

Samples were spun at $3,000 \mathrm{~Hz}$, and two different types of one-dimensional (1D) proton spectra were acquired using a water-suppressed spin-echo Carr-Purcell-Meiboom -Gill (CPMG) pulse sequence [ $90^{\circ}-\left(\tau-180^{\circ}-\tau\right) n$-acquisition], as previously described (23). CPMG includes inter-pulse delay $(\tau=2 \pi / \omega \mathrm{r}=400 \mu \mathrm{sec}) ; 256$ transients; spectral width of $7.2 \mathrm{kHz} ; 8 \mathrm{k}$ data points; and TR=3 sec. Further investigation of the metabolites was performed using a novel approach that combines a two-dimensional (2D), solid-state, HRMAS proton $\left({ }^{1} \mathrm{H}\right)$ NMR method, total through-bond correlation spectroscopy (TOBSY) (24), which maximizes the advantages of HRMAS, and a robust classification strategy. Typical acquisition parameters were as follows: $2 \mathrm{k}$ points direct dimension (13 ppm spectral width), 200 points indirect dimension (7.5 ppm spectral width), 8 scans with 2 dummy scans, $1 \mathrm{sec}$ water presaturation, $2 \mathrm{sec}$ total repetition time, $45 \mathrm{msec}$ mixing time and total acquisition time $45 \mathrm{~min}$.

Quantification of metabolites. Concentrations using MestReC software (Mestrelab Research, Santiago de Compostela, Spain), an automated fitting routine based on the Levenberg-Marquardt algorithm, was applied after manual peak selection, adjusting peak positions, intensities, linewidths and Lorentzian/Gaussian ratio until the residual spectrum was minimized, as previously described $(25,26)$. The metabolite concentration $(\mathrm{mol} / \mathrm{kg}$ ) was calculated using the following equation:

$\frac{\text { Mass TSP }(\mathrm{mg})}{\text { Mol Weight (TSP) }} \times \frac{\text { Met Peak Area }}{\text { TSP Peak Area }} \times \frac{\mathrm{N}_{\text {TSP }}}{\mathrm{N}_{\text {Met }}} \times \frac{1,000 \mathrm{~g} / \mathrm{kg}}{\text { Sample Weight }(\mathrm{mg})}$

where mass TSP was constant $(0.069 \mathrm{mg})$, the molecular weight of TSP $=172.23 \mathrm{~g} / \mathrm{mol}$, metabolites (Met), $\mathrm{N}_{\mathrm{TSP}}$ is the number of proton of TSP $\left(9{ }^{1} \mathrm{H}\right)$ and $\mathrm{N}_{\text {Met }}$ is the number of proton of metabolites, as previously described (27).

Statistical analysis. The data are presented as the means \pm standard error. Statistical analysis was performed using the Student's t-test: two paired samples were used for means. A p-value $<0.05$ was considered to indicate a statistically significant difference (Table I).

Microarray hybridization. Biotinylated cRNA was generated with $10 \mu \mathrm{g}$ total cellular RNA, according to the protocol outlined by Affymetrix Inc. (Santa Clara, CA, USA). cRNA was hybridized onto GeneChip P. aeruginosa Genome Array oligonucleotide arrays (Affymetrix Inc.), stained, washed and scanned according to the Affymetrix protocol.

Genomic data analysis. The PA14 cells were grown in $50 \mathrm{ml}$ of Luria-Bertani (LB) broth at $37^{\circ} \mathrm{C}$ without agitation and with $3.0 \mathrm{mM}$ 2-aminoacetophenone (2-AA). Triplicate samples from 2 independent experiments were harvested at $\mathrm{OD}_{600}=2.0$, and total RNA was purified using the RNAeasy spin column (Qiagen, Valencia, CA). The quality of the RNA was analyzed using a BioAnalyzer system (Agilent Technologies, Santa Clara, CA, USA). cDNA synthesis, labeling and hybridization was 


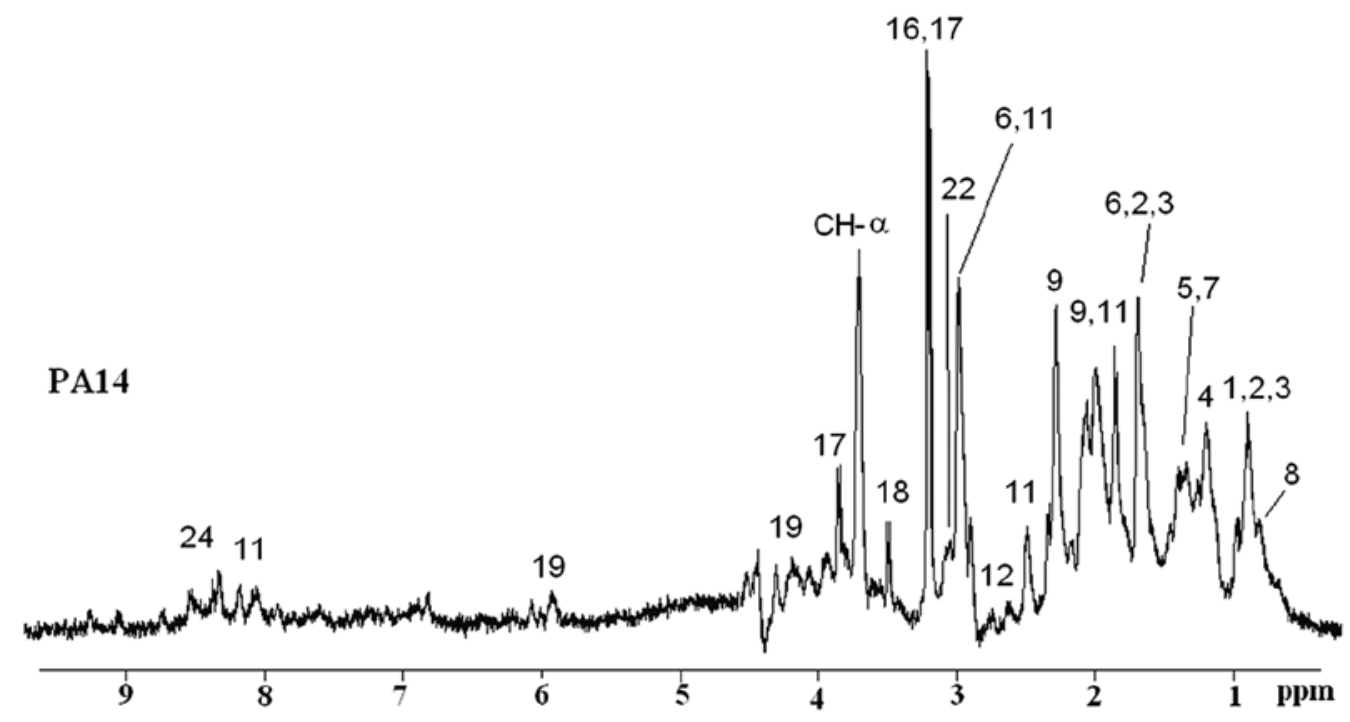

Figure 1. One-dimensional (1D) ${ }^{1} \mathrm{H}$-Carr-Purcell-Meiboom-Gill (CPMG) of PA14 are reported, and different metabolites are labeled: 1, leucine; 2, isoleucine; 3, valine; 4, lactate; 5, alanine; 6, lysine; 7, bonded alanine; 8, phospholipids; 9, glutamate; 11, glutathione; 12, aspartate; 16, choline; 17, betaine compounds; 18 , glycine; 19, uridine monophosphate (UMP); 22, citrulline; 24, nicotinamide adenine dinucleotide (NAD)

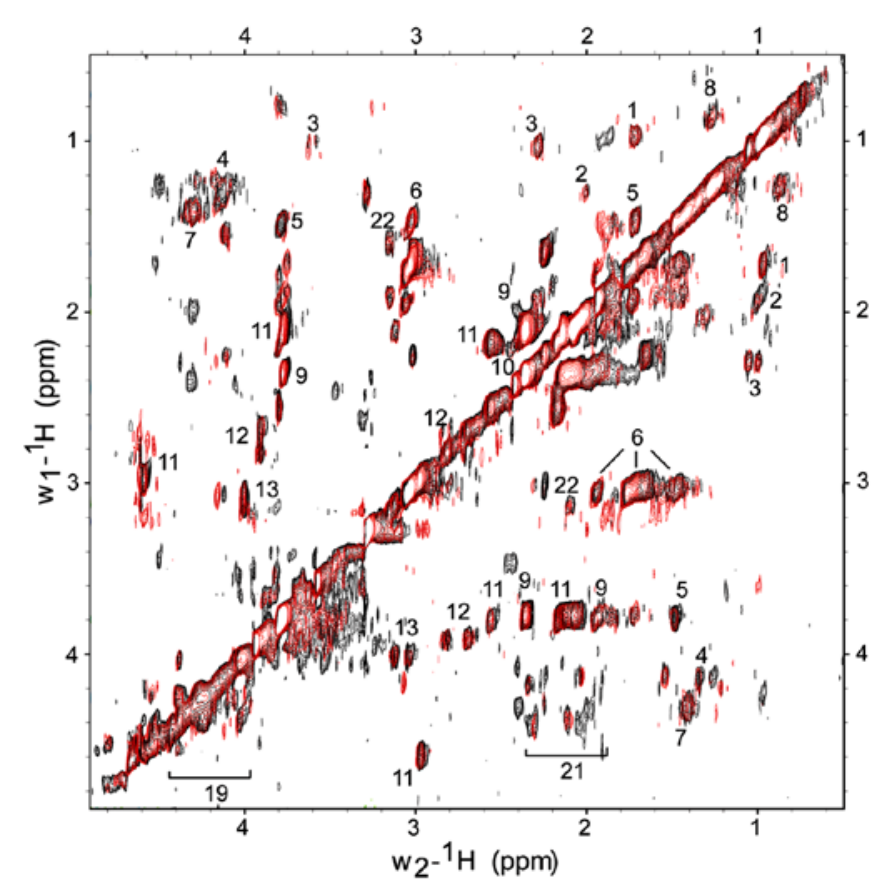

Figure 2. Representative two-dimensional (2D) ${ }^{1} \mathrm{H}-{ }^{1} \mathrm{H}$ total through-bond correlation spectroscopy (TOBSY) high-resolution magic angle spinning (HRMAS) nuclear magnetic resonance (NMR) spectra NMR from PA14 are shown. Superimposed 2D TOBSY of PA14 (red) and PA14 + 2-AA (black). The capsular polysaccharides are detected due to their $\mathrm{N}$-acetyl signal (represented by the number 21$),(2.02 \div 2.33 / 4.10 \div 4.33 \mathrm{ppm})$. Also, glutathione (represented by the number 11), a major cell antioxidant, is detected with higher resolution than in 1D. The major difference is in the 21 signals derive from the $\mathrm{N}$-acetyl compound.

performed according to the GeneChip ${ }^{\circledR}$ P. aeruginosa Genome array (Affymetrix Inc).

The Affymetrix DAT files were processed using the Affymetrix-Gene Chip Operating System (GCOS) to create .Cel files. The raw intensity .Cel files from the 12 chips, 3 replicates each, were normalized by robust multi-chip analysis (RMA) (Bioconductor release 1.7) with PM-only models. Array quality control (QC) metrics generated by Affymetrix Microarray Suite 5.0 were used to assess the hybridization quality. The normalized expression values were analyzed by significance analysis of microarrays (SAM) using the permuted unpaired two-class test. Three replicates of PA14 in the absence of 2-AA were used as the controls and the experimental groups consisted of 2-AA-treated PA14 cultures in 3 replicates. Genes whose transcript levels exhibited either up- or downregulation (absolute fold change of $>1.5$ ) and a q-value of $<20 \%$ in response to 2-AA treatment versus the controls were further analyzed.

\section{Results and Discussion}

NMR metabolomic and genomic analysis was carried out on PA, strain PA14. A representative 1D ${ }^{1} \mathrm{H}$ CPMG HRMAS NMR spectrum obtained from live bacterial cells of the PA14 strain is shown in Fig. 1. The spectrum allows for the direct identification of several metabolites, such as aminoacids, osmolites and phospholipids [1, leucine; 2 , isoleucine; 3 , valine; 4 , lactate; 5, alanine; 6 , lysine; 7 , bonded alanine; 8 , phospholipids; 9 , glutamate; 10 , glutamine; 12 , aspartate; 16 , phospho-choline; 17, betaine compounds; 18 , glycine; 19 , uridine monophosphate (UMP); 22, citrulline; 24, nicotinamide adenine dinucleotide (NAD)]. This novel approach to bacterial cell analysis is fast and provides important information. However, the peaks overlap in the 1D NMR spectra, and it is thus difficult to assign particular peaks to specific molecules. $2 \mathrm{D}{ }^{1} \mathrm{H}-{ }^{1} \mathrm{H}$ TOBSY HRMAS was performed in order to better identify and resolve particular molecules, thus completing the metabolic profiling of bacterial cells (Fig. 2). Fig. 2 shows representative superimposed 2D ${ }^{1} \mathrm{H}-{ }^{-} \mathrm{H}$ TOBSY HRMAS NMR spectra of PA14 and PA14 + 2-AA. Compared to 1D spectra, 2D NMR spectra allowed for the clearer discrimination of signals. In the 2D NMR spectra, additional metabolites were identified, such as: 11 , glutathione; 13 , cysteine; $21, \mathrm{~N}$-acetyl signal; 23 , tyrosine; 
Table I. ${ }^{1} \mathrm{H}$ chemical shift $(\delta, \mathrm{ppm})$ of metabolites detected in 1D and 2D HRMAS spectra of bacterial cells.

\begin{tabular}{|c|c|c|c|c|c|c|c|}
\hline Entry & Metabolite & $\delta{ }^{1} \mathrm{H}$ & Assignment & PA14 (mmol/g) & $2-\mathrm{AA}(\mathrm{mmol} / \mathrm{g})$ & $\% \Delta$ & p-value \\
\hline 1 & Leucine & $\begin{array}{l}0.95 \text { (d) } \\
0.97 \text { (d) } \\
1.70 \\
1.72 \\
3.75\end{array}$ & $\begin{array}{l}\delta-\mathrm{CH}_{3} \\
\delta-\mathrm{CH}_{3} \\
\gamma-\mathrm{CH} \\
\beta-\mathrm{CH}_{2} \\
\alpha-\mathrm{CH}\end{array}$ & $0.40 \pm 0.05$ & $0.51 \pm 0.11$ & +28 & 0.40 \\
\hline 2 & Ile & $\begin{array}{l}0.99(\mathrm{~d}) \\
1.94 \\
3.75\end{array}$ & $\begin{array}{l}\delta-\mathrm{CH}_{3} \\
\beta-\mathrm{CH}_{2} \\
\alpha-\mathrm{CH}\end{array}$ & $0.15 \pm 0.03$ & $0.22 \pm 0.06$ & +47 & 0.18 \\
\hline 3 & Valine & $\begin{array}{l}0.99(\mathrm{~d}) \\
1.04(\mathrm{~d}) \\
2.25 \\
3.61\end{array}$ & $\begin{array}{l}\gamma-\mathrm{CH}_{3} \\
\gamma-\mathrm{CH}_{3} \\
\beta-\mathrm{CH} \\
\alpha-\mathrm{CH}\end{array}$ & $0.21 \pm 0.02$ & $0.32 \pm 0.05$ & +52 & 0.11 \\
\hline 4 & Lactate & $\begin{array}{l}1.33(\mathrm{~d}) \\
4.11(\mathrm{q})\end{array}$ & $\begin{array}{l}\mathrm{CH}_{3} \\
\mathrm{CH}\end{array}$ & $0.10 \pm 0.02$ & $0.20 \pm 0.02$ & +100 & 0.009 \\
\hline 5 & Alanine & $\begin{array}{l}1.48(\mathrm{~d}) \\
3.79(\mathrm{q})\end{array}$ & $\begin{array}{l}\beta-\mathrm{CH}_{3} \\
\alpha-\mathrm{CH}\end{array}$ & $0.22 \pm 0.02$ & $0.38 \pm 0.03$ & +73 & 0.006 \\
\hline 6 & Lysine & $\begin{array}{l}3.04(t) \\
1.73 \\
1.48 \\
1.91 \\
3.79(t)\end{array}$ & $\begin{array}{l}\varepsilon-\mathrm{CH}_{2} \\
\delta-\mathrm{CH}_{2} \\
\gamma-\mathrm{CH}_{2} \\
\beta-\mathrm{CH}_{2} \\
\alpha-\mathrm{CH}\end{array}$ & $0.21 \pm 0.03$ & $0.18 \pm 0.03$ & -14 & 0.45 \\
\hline 7 & Phospholipids & $\begin{array}{l}0.89 \\
1.27 \\
3.27\end{array}$ & $\begin{array}{l}\mathrm{CH}_{3} \\
\mathrm{CH}_{2} \\
\mathrm{~N}^{+}\left(\mathrm{CH}_{3}\right)_{3}\end{array}$ & Traces & Traces & & \\
\hline 8 & Glutamate & $\begin{array}{l}2.35 \\
2.06,2.15 \\
3.77(\mathrm{t})\end{array}$ & $\begin{array}{l}\gamma-\mathrm{CH}_{2} \\
\beta-\mathrm{CH}_{2} \\
\alpha-\mathrm{CH}\end{array}$ & $0.16 \pm 0.04^{b}$ & $0.22 \pm 0.05^{\mathrm{b}}$ & +38 & 0.35 \\
\hline 9 & Glutamine & $\begin{array}{l}2.48 \\
2.14 \\
3.79(t)\end{array}$ & $\begin{array}{l}\gamma-\mathrm{CH}_{2} \\
\beta-\mathrm{CH}_{2} \\
\alpha-\mathrm{CH}\end{array}$ & $0.089^{\mathrm{a}}$ & $0.08 \pm 0.004^{\mathrm{b}}$ & - & - \\
\hline 10 & Glutathione & $\begin{array}{l}2.55 \\
2.16 \\
3.80 \\
2.96 \\
4.57 \\
3.77\end{array}$ & $\begin{array}{l}\gamma-\mathrm{CH}_{2} \text { Glu } \\
\beta-\mathrm{CH}_{2} \text { Glu } \\
\alpha-\mathrm{CH}_{\mathrm{Glu}} \\
\beta-\mathrm{CH}_{2} \mathrm{Cys} \\
\alpha-\mathrm{CH} \mathrm{Cys} \\
\mathrm{CH}_{2} \mathrm{Gly}\end{array}$ & Traces & Traces & & \\
\hline 11 & Aspartic acid & $\begin{array}{l}2.68,2.82 \\
3.90(\mathrm{dd})\end{array}$ & $\begin{array}{l}\beta-\mathrm{CH}_{2} \\
\alpha-\mathrm{CH}\end{array}$ & nd & $0.041^{\mathrm{a}}$ & & \\
\hline 12 & Cysteine & $\begin{array}{l}3.05,3.08 \\
3.98\end{array}$ & $\begin{array}{l}\beta-\mathrm{CH}_{2} \\
\alpha-\mathrm{CH}\end{array}$ & $0.24 \pm 0.05^{\mathrm{b}}$ & $0.25 \pm 0.05$ & +4 & 0.81 \\
\hline 13 & Creatine & $\begin{array}{l}3.04(\mathrm{~s}) \\
3.92(\mathrm{~s})\end{array}$ & $\begin{array}{l}\mathrm{NCH}_{3} \\
\mathrm{CH}_{2}\end{array}$ & Traces & Traces & & \\
\hline 14 & Acetate & $1.92(\mathrm{~s})$ & $\mathrm{CH}_{3}$ & $0.31 \pm 0.05$ & $1.05 \pm 0.24$ & +239 & 0.04 \\
\hline 15 & Phosphocholine & $\begin{array}{l}3.21(\mathrm{~s}) \\
3.60 \\
4.17\end{array}$ & $\begin{array}{l}\mathrm{N}\left(\mathrm{CH}_{3}\right)_{3} \\
\mathrm{NCH}_{2} \\
\mathrm{OCH}_{2}\end{array}$ & $0.04 \pm 0.01$ & $0.07 \pm 0.01$ & +75 & 0.20 \\
\hline 16 & Betaine compound & $\begin{array}{l}3.27 \\
3.90\end{array}$ & $\begin{array}{l}\mathrm{NCH}_{3} \\
\mathrm{NCH}_{2}\end{array}$ & $0.45 \pm 0.03$ & $1.31 \pm 0.3$ & +191 & 0.04 \\
\hline
\end{tabular}


Table I. Continued.

\begin{tabular}{|c|c|c|c|c|c|c|c|}
\hline Entry & Metabolite & $\delta{ }^{1} \mathrm{H}$ & Assignment & PA14 (mmol/g) & $2-\mathrm{AA}(\mathrm{mmol} / \mathrm{g})$ & $\% \Delta$ & p-value \\
\hline 17 & Glycine & $3.56(\mathrm{~s})$ & $\mathrm{CH}_{2}$ & $0.45 \pm 0.19^{b}$ & $0.66 \pm 0.32$ & +47 & 0.50 \\
\hline 18 & N-Ac- from PS & $\begin{array}{l}2.01(\mathrm{~s}) \\
2.08 \\
2.33 \\
2.39 \\
4.32 \\
4.41 \\
5.44\end{array}$ & $\begin{array}{l}\mathrm{CH}_{3} \\
\mathrm{CH}_{3} \\
\mathrm{CH}_{2} \\
\mathrm{CH}_{2} \\
\mathrm{CH}_{2} \\
\mathrm{CH}_{2}\end{array}$ & $0.26 \pm 0.02$ & $0.46 \pm 0.01$ & +77 & 0.01 \\
\hline 19 & Citrulline & $\begin{array}{l}1.54 \\
1.88 \\
3.15 \\
3.76\end{array}$ & $\begin{array}{l}\beta-\mathrm{CH}_{2} \\
\gamma-\mathrm{CH}_{2} \\
\delta-\mathrm{CH}_{2} \\
\alpha-\mathrm{CH}\end{array}$ & $0.15 \pm 0.01$ & $0.32 \pm 0.02$ & +113 & 0.003 \\
\hline 20 & Uracil & $\begin{array}{l}5.80 \\
7.53\end{array}$ & $\begin{array}{l}\text { 5-CHur } \\
\text { 6-CHur }\end{array}$ & Traces & nd & & \\
\hline 21 & NAD & $\begin{array}{l}8.21 \\
8.93 \\
9.23 \\
9.44\end{array}$ & $\begin{array}{l}\text { N5 ring } \\
\text { N3 ring } \\
\text { N2 ring } \\
\text { N6 ring }\end{array}$ & Traces & Traces & & \\
\hline 22 & Tyrosine & $\begin{array}{l}3.06,3.15 \\
3.93(\mathrm{dd}) \\
6.88 \\
7.18\end{array}$ & $\begin{array}{l}\beta-\mathrm{CH}_{2} \\
\alpha-\mathrm{CH} \\
\text { Hortho } \\
\text { Hmeta }\end{array}$ & nd & Traces & & \\
\hline 23 & UDP & $\begin{array}{l}5.98 . \\
4.38 \\
4.34 \\
4.23 \\
4.02 \\
5.97 \\
8.11(\mathrm{~d})\end{array}$ & $\begin{array}{l}\text { 1-CHrib } \\
\text { 2-CHrib } \\
\text { 3-CHrib } \\
\text { 4-CHrib } \\
\text { 5-CHrib } \\
\text { 4-CHur } \\
\text { 5-CHur }\end{array}$ & $\begin{array}{l}\text { Related } \\
\text { to N-Ac }\end{array}$ & $\begin{array}{l}\text { Related } \\
\text { to N-Ac }\end{array}$ & & \\
\hline 24 & Phenylalanine & $\begin{array}{l}3.11,3.28 \\
3.98 \\
7.33 \\
7.38 \\
7.43\end{array}$ & $\begin{array}{l}\beta-\mathrm{CH}_{2} \\
\alpha-\mathrm{CH} \\
\text { Hortho } \\
\text { Hpara } \\
\text { Hmeta }\end{array}$ & nd & Traces & & \\
\hline
\end{tabular}

$\% \Delta=[(\mathrm{w} 1-\mathrm{w} 2) / \mathrm{w} 2] \mathrm{x} 100=$ where $\mathrm{w} 1=2-\mathrm{AA}$ values and $\mathrm{w} 2=$ PA14 values. ${ }^{\mathrm{a}}$ One sample; ${ }^{\mathrm{b}}$ two samples. The absolute quantification is derived from the 1D Carr-Purcell-Meiboom-Gill (CPMG) experiment. The concentration are mmol/g. 1D, one-dimensional; 2D, two-dimensional; HRMAS, high-resolution magic angle spinning; 2-AA, 2-amino acetophenone; NAD, nicotinamide adenine dinucleotide; UDP, uridine diphosphate; nd, not detected.

24, phenylalanine. As shown for the TOBSY MR spectra, the capsular polysaccharides were identified due to their N-acetyl signal (represented by the number 21$)(2.02 \div 2.33 / 4.10 \div 4.33 \mathrm{ppm})$. In addition, glutathione (represented by the number 11), a major cell antioxidant, was detected with higher resolution than in the $1 \mathrm{D}$ spectrum. The major difference was in the 18 signals derived from the $\mathrm{N}$-acetyl compound.

The 24 metabolites were identified from the combined analysis of the 1D and 2D spectra of PA and are listed in Table I. We detected $\mathrm{N}$-acetyl compound (signal at $2.02 \div 2.33 / 4.10 \div 4.33 \mathrm{ppm}$ ), which is a constituent of the capsular polysaccharides (28). The use of TOSBY in HRMAS enabled us to detect all these metabolites, even when they were present in small amounts and hidden within other resonances (Fig. 2). The acetylation of bacterial surface polysaccharides, such as capsular polysaccharides (CPSs), is common in pathogens and has been shown to have immunogenic and functional importance (29). Other metabolites, such as betaine compounds were 


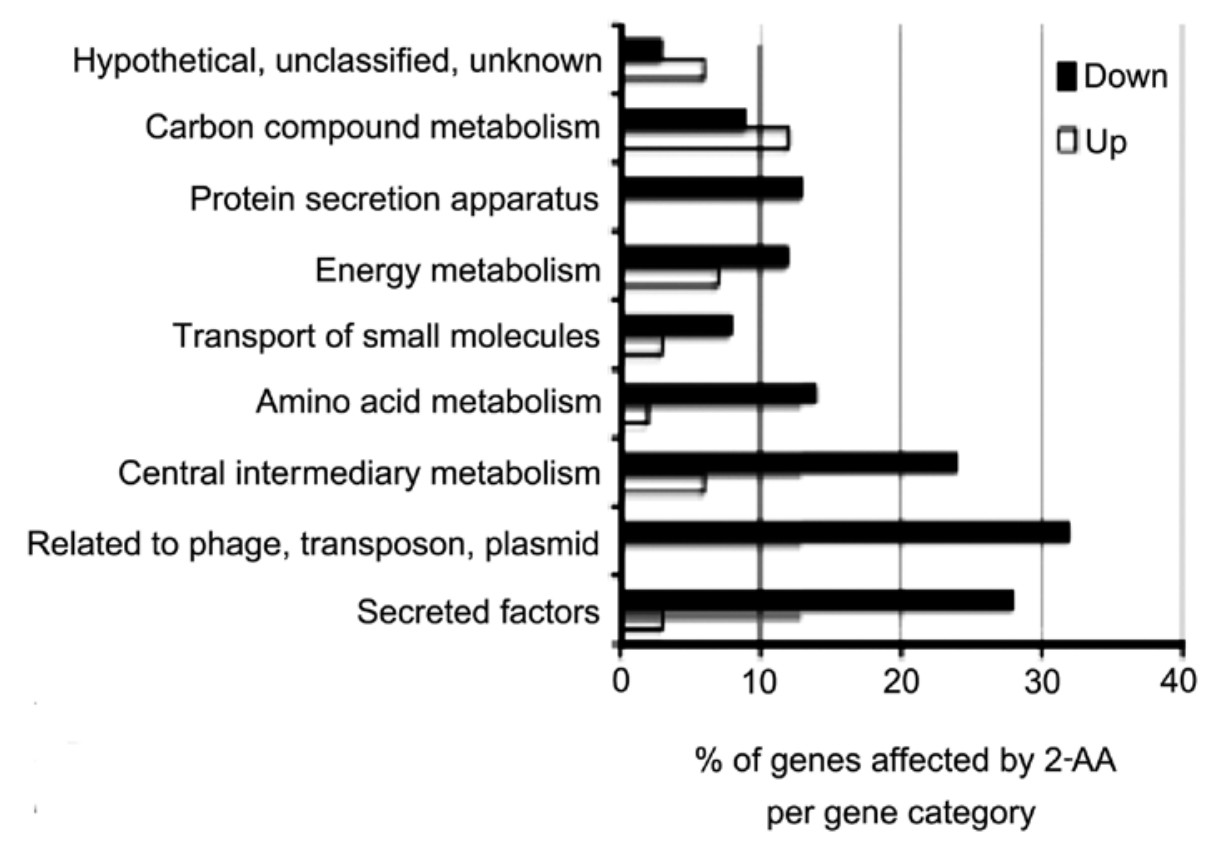

Figure 3. Functional classification of genes changed by 2-amino acetophenone (2-AA) compared to untreated PA14 cells.

also detected. These molecules are well known to act as osmoprotectors and have been shown to preserve L-homoserine lactone (HSL), the Pseudomonas Quinolone Signal (PQS) and 2-heptyl-4-quinolone (HHQ) bacterial cell-to-cell signaling (30). Betaine is synthesized from betaine aldehyde via the bet $\mathrm{B}$ gene product (31). Betaine compounds were increased by 2 -AA, thus indicating that 2-AA promotes osmoprotection to possibly increase bacterial survival in harsh conditions of the host environment.

The expression of the enzyme betaine aldehyde, $\mathrm{NAD}(\mathrm{P})^{+}$ oxidoreductase [EC .2.1.8, betaine aldehyde dehydrogenase (BADH)], involved in the second step of choline metabolism; betaine aldehyde dehydrogenase is induced by choline even when PA cells are grown in the presence of other carbon and nitrogen sources, such as glucose and ammonium (33). BADH from PA thus appears to be a suitable target for antimicrobial agents. In addition, in order to participate in the catabolism of choline, this enzyme may be crucial in the mechanisms of defense against osmotic and oxidative stress, both of which are conditions present in infected tissues (34). The acid product of the BADH from the PA reaction, glycine betaine, is a very efficient osmoprotectant and most likely acts as such in PA cells growing in the hyperosmotic environment of infected tissues (35). Most importantly, the inhibition of PaBADH will give rise to increased intracellular levels of betaine aldehyde, a highly toxic compound (36). In fact, a PA strain defective in BADH cannot grow in choline, even if glucose is also present in the growth medium, due to the toxicity of betaine aldehyde (36). The finding that PA-BADH is expressed in the presence of other carbon compounds, such as glucose, provided that choline is also present in the bacterial growth medium (32), supports the possibility of using its inhibition as a means to combat the pathogen.

In relation to citrulline, we know that ornithine carbamoyltransferase (OTCase), (EC 2.1.3.3) catalyzes the carbamoylation of the $\gamma$-amino group of ornithine by carbamoyl phosphate to provide citrulline and inorganic phosphate (37). This thermo- dynamically favored reaction operates in the synthesis of the amino acid, as performed in this study. PA catabolic OTCase catalyzes the second reaction in the arginine deiminase pathway, which is involved in ATP synthesis under conditions of energy depletion (38-40). The coupling system involving the production and deamination of ATP from ADP, citrulline and Pi in the presence of carbamate may be used to determine the catabolic OTCase activity (41). In this study, in the presence of 2-AA, we observed an increase in citrulline in the bacterial cells.

Comparing the whole-genome transcriptome profiles of PA cells grown with or without 2-AA demonstrates that this in vivo signal molecule reprograms the expression of 614 genes at late exponential and early stationary growth, when many virulence-related functions are most highly expressed (42). The analysis of the respective functions of these genes (Fig. 3) demonstrated that they encode several metabolic functions, including central intermediary, amino acid, carbon and energy metabolism pathways. As such, 2-AA promotes profound metabolic changes in PA14 cells. We further performed whole cell HRMAS NMR spectroscopy to identify and quantify the PA14 cell metabolome (Fig. 2), using a novel method, TOBSY, which combines 1D and 2D solid-state, ${ }^{1} \mathrm{H}$ HRMAS NMR (24). TOBSY maximizes the advantages of HRMAS and, using a robust classification strategy, the 2D data enable a more complete determination of metabolites. While certain metabolites are clearly detected and quantified using 1D spectra, including glycine, betaine compounds and glutamate (Fig. 2); other metabolites, including lysine, UMP and citrulline, require 2D NMR to resolve and quantify their resonances that overlap in the 1D spectra. The combined use of 1D and 2D spectra can thus provide complete and unambiguous metabolite identification in complex biological samples. Comparing the whole-genome transcriptome profiles and metabolome studies of PA14 cells grown with or without 2-AA demonstrates that this molecule profoundly reprograms the gene expression and metabolism of the cell. 
In conclusion, the combination of $1 \mathrm{D}$ and $2 \mathrm{D}{ }^{1} \mathrm{H}$ HRMAS NMR is a powerful in vivo technique which can be used in a variety of studies, including studies using live bacterial cells, as reported herein. Multi-dimensional HRMAS NMR using intact bacterial cells represents a promising method that may provide in vivo information on metabolomics in live bacteria. To this end, it can be complementary to existing chemical and biological methods, and likely complementary to mass spectrometry, which is a powerful metabolomics technique, but nevertheless is also a destructive technique. On the other hand, multi-dimensional in vivo HRMAS NMR is a promising method to determine the in vivo metabolome of live intact bacterial cells and the effects of compounds produced by PA, as they may induce the emergence of phenotypes that promote chronic infections in in vitro and in vivo (animal) models. To this end, our in vivo ${ }^{1} \mathrm{H}$ HRMAS NMR technique should prove a helpful tool in gene function validation, the study of pathogenesis mechanisms, the classification of microbial strains into functional/clinical groups, and the testing of bacterial molecules as performed here. Moreover, the technique may be used to find drugs that block the conversion of bacterial cells into the persister state and enables them to survive traditional antibiotic treatments and thereby cause persistent and relapsing infections.

\section{Acknowledgements}

This study was supported in part by Shriners Hospital for Children research grants 87100 and 85200 in addition to NIH grant AI105902 to LGR and NIH grant R01AI134857. We would like to thank Dr Scott Stachel for providing comments on the manuscript and editing.

\section{Competing interests}

The authors declare that they have no competing interests.

\section{References}

1. Bodey GP: Infectious diseases update: 1982. Summary of a symposium. Rev Infect Dis 5: 232-234, 1983.

2. Koch C and Høiby N: Pathogenesis of cystic fibrosis. Lancet 341: 1065-1069, 1993

3. Bassler BL and Losick R: Bacterially speaking. Cell 125: 237-246, 2006

4. Hoffman LR, Déziel E, D'Argenio DA, Lépine F, Emerson J, McNamara S, Gibson RL, Ramsey BW and Miller SI: Selection for Staphylococcus aureus small-colony variants due to growth in the presence of Pseudomonas aeruginosa. Proc Natl Acad Sci USA 103: 19890-19895, 2006.

5. Kesarwani M, Hazan R, He J, Que YA, Apidianakis Y, Lesic B, Xiao G, Dekimpe V, Milot S, Deziel E, et al: A quorum sensing regulated small volatile molecule reduces acute virulence and promotes chronic infection phenotypes. PLoS Pathog 7: e1002192, 2011.

6. Dmitriev B, Toukach F and Ehlers S: Towards a comprehensive view of the bacterial cell wall. Trends Microbiol 13: 569-574, 2005.

7. Li W: Multidimensional HRMAS NMR: a platform for in vivo studies using intact bacterial cells. Analyst 131: 777-781, 2006

8. Griffin JL: Metabonomics: NMR spectroscopy and pattern recognition analysis of body fluids and tissues for characterisation of xenobiotic toxicity and disease diagnosis. Curr Opin Chem Biol 7: 648-654, 2003.

9. Tweeddale H, Notley-McRobb L and Ferenci T: Effect of slow growth on metabolism of Escherichia coli, as revealed by global metabolite pool ('metabolome') analysis. J Bacteriol 180: 5109-5116, 1998
10. Tweeddale H, Notley-McRobb L and Ferenci T: Assessing the effect of reactive oxygen species on Escherichia coli using a metabolome approach. Redox Rep 4: 237-241, 1999.

11. Liu X, Ng C and Ferenci T: Global adaptations resulting from high population densities in Escherichia coli cultures. J Bacteriol 182: 4158-4164, 2000.

12. Himmelreich U, Somorjai RL, Dolenko B, Lee OC, Daniel HM, Murray R, Mountford CE and Sorrell TC: Rapid identification of Candida species by using nuclear magnetic resonance spectroscopy and a statistical classification strategy. Appl Environ Microbiol 69: 4566-4574, 2003.

13. Gudlavalleti SK, Szymanski CM, Jarrell HC and Stephens DS: In vivo determination of Neisseria meningitidis serogroup A capsular polysaccharide by whole cell high-resolution magic angle spinning NMR spectroscopy. Carbohydr Res 341: 557-562, 2006.

14. Szymanski CM, Michael FS, Jarrell HC, Li J, Gilbert M, Larocque S, VinogradovE and Brisson JR: Detection of conserved $\mathrm{N}$-linked glycans and phase-variable lipooligosaccharides and capsules from campylobacter cells by mass spectrometry and high resolution magic angle spinning NMR spectroscopy. J Biol Chem 278: 24509-24520, 2003.

15. Righi V, Constantinou C, Kesarwani M, Rahme LG and Tzika AA: Live-cell high resolution magic angle spinning magnetic resonance spectroscopy for analysis of metabolomics. Biomed Rep 1: 707-712, 2013.

16. Weybright P, Millis K, Campbell N, Cory DG and Singer S: Gradient, high-resolution, magic angle spinning ${ }^{1} \mathrm{H}$ nuclear magnetic resonance spectroscopy of intact cells. Magn Reson Med 39: 337-345, 1998

17. Blankenberg FG, Storrs RW, Naumovski L, Goralski T and Spielman D: Detection of apoptotic cell death by proton nuclear magnetic resonance spectroscopy. Blood 87: 1951-1956, 1996.

18. Cheng LL, Ma MJ, Becerra L, Ptak T, Tracey I, Lackner A and González RG: Quantitative neuropathology by high resolution magic angle spinning proton magnetic resonance spectroscopy. Proc Natl Acad Sci USA 94: 6408-6413, 1997.

19. Cheng LL, Newell K, Mallory AE, Hyman BT and Gonzalez RG: Quantification of neurons in Alzheimer and control brains with ex vivo high resolution magic angle spinning proton magnetic resonance spectroscopy and stereology. Magn Reson Imaging 20: 527-533, 2002.

20. Millis KK, Maas WE, Cory DG and Singer S: Gradient, high-resolution, magic-angle spinning nuclear magnetic resonance spectroscopy of human adipocyte tissue. Magn Reson Med 38: 399-403, 1997.

21. Righi V, Apidianakis Y, Mintzopoulos D, Astrakas L, Rahme LG and Tzika AA: In vivo high-resolution magic angle spinning magnetic resonance spectroscopy of Drosophila melanogaster at 14.1 $\mathrm{T}$ shows trauma in aging and in innate immune-deficiency is linked to reduced insulin signaling. Int J Mol Med 26: 175-184, 2010.

22. Fitzsimmons LF, Hampel KJ and Wargo MJ: Cellular choline and glycine betaine pools impact osmoprotection and phospholipase C production in Pseudomonas aeruginosa. J Bacteriol 194: 4718-4726, 2012.

23. Meiboom S and Gill D: Modified Spin-Echo method for measuring nuclear relaxation Times. Rev Sci Instrum 29: 688-691, 1958.

24. Andronesi OC, Mintzopoulos D, Struppe J, Black PM and Tzika AA: Solid-state NMR adiabatic TOBSY sequences provide enhanced sensitivity for multidimensional high-resolution magic-angle-spinning ${ }^{1} \mathrm{H}$ MR spectroscopy. J Magn Reson 193: 251-258,2008.

25. Levenberg K: A method for the solution of certain non-linear problems in least squares. Q Appl Math 2: 164-168, 1944.

26. Marquardt D: An algorithm for least-squares estimation of nonlinear parameters. SIAM J Appl Math 11: 431-441, 1963.

27. Swanson MG, Zektzer AS, Tabatabai ZL, Simko J, Jarso S, Keshari KR, Schmitt L, Carroll PR, Shinohara K, Vigneron DB and Kurhanewicz J: Quantitative analysis of prostate metabolites using ${ }^{1} \mathrm{H}$ HR-MAS spectroscopy. Magn Reson Med 55: 12571264,2006

28. Gudlavalleti SK, Datta AK, Tzeng YL, Noble C, Carlson RW and Stephens DS: The Neisseria meningitidis serogroup A capsular polysaccharide O-3 and O-4 acetyltransferase. J Biol Chem 279: 42765-42773, 2004.

29. Cress BF, Englaender JA, He W, Kasper D, Linhardt RJ and Koffas MAG: Masquerading microbial pathogens: capsular polysaccharides mimic host-tissue molecules. FEMS Microbiol Rev 38: 660-697, 2014. 
30. Bazire A, Diab F, Taupin L, Rodrigues S, Jebbar M and Dufour A: Effects of osmotic stress on rhamnolipid synthesis and time-course production of cell-to-cell signal molecules by Pseudomonas aeruginosa. Open Microbiol J. 3: 128-135, 2009.

31. Lesic B, Lépine F, Déziel E, Zhang J, Zhang Q, Padfield K, Castonguay MH, Milot S, Stachel S, Tzika AA, et al: Inhibitors of pathogen intercellular signals as selective anti-infective compounds. PLoS Pathog 3: 1229-1239, 2007.

32. Ostroff RM, Vasil AI and Vasil ML: Molecular comparison of a nonhemolytic and a hemolytic phospholipase $\mathrm{C}$ from Pseudomonas aeruginosa. J Bacteriol 172: 5915-5923, 1990.

33. Velasco-García R, Villalobos MA, Ramírez-Romero MA, Mújica-Jiménez C, Iturriaga $\mathrm{G}$ and Muñoz-Clares RA: Betaine aldehyde dehydrogenase from Pseudomonas aeruginosa: cloning, over-expression in Escherichia coli, and regulation by choline and salt. Arch Microbiol 185: 14-22, 2006.

34. Kilbourn JP: Bacterial content and ionic composition of sputum in cystic fibrosis. Lancet 1: 334, 1978.

35. D'Souza-Ault MR, Smith LT and Smith GM: Roles of $\mathrm{N}$-acetylglutaminylglutamine amide and glycine betaine in adaptation of Pseudomonas aeruginosa to osmotic stress. Appl Environ Microbiol 59: 473-478, 1993.

36. Sage AE, Vasil AI and Vasil ML: Molecular characterization of mutants affected in the osmoprotectant-dependent induction of phospholipase C in Pseudomonas aeruginosa PAO1. Mol Microbiol 23: 43-56, 1997.
37. Sainz G, Tricot C, Foray MF, Marion D, Dideberg O and Stalon V: Kinetic studies of allosteric catabolic ornithine carbamoyltransferase from Pseudomonas aeruginosa. Eur J Biochem 251: 528-533, 1998

38. Mercenier A, Simon JP, Vander Wauven C, Haas D and Stalon V: Regulation of enzyme synthesis in the arginine deiminase pathway of Pseudomonas aeruginosa. J Bacteriol 144: 159-163, 1980.

39. Stalon V and Mercenier A: L-arginine utilization by Pseudomonas species. J Gen Microbiol 130: 69-76, 1984.

40. Vander Wauven C, Piérard A, Kley-Raymann M and Haas D: Pseudomonas aeruginosa mutants affected in anaerobic growth on arginine: evidence for a four-gene cluster encoding the arginine deiminase pathway. J Bacteriol 160: 928-934, 1984.

41. Ramos F, Stalon V, Piérard A and Wiame JM: The specialization of the two ornithine carbamoyltransferases of Pseudomonas. Biochim Biophys Acta 139: 98-106, 1967.

42. Déziel E, Gopalan S, Tampakaki AP, Lépine F, Padfield KE, Saucier M, Xiao G and Rahme LG: The contribution of MvfR to Pseudomonas aeruginosa pathogenesis and quorum sensing circuitry regulation: multiple quorum sensing-regulated genes are modulated without affecting lasRI, rhlRI or the production of N-acyl-L-homoserine lactones. Mol Microbiol 55: 998-1014, 2005. 